ented to the meeting delegates from the Royal Society of Canada, the American Meteorological Society and the History of Science Society. The first formal paper, entitled "Telescope, Microscope, and Barometer as a Point of Departure for the Natural Sciences", was delivered by Prof. Louis C. Karpinski, of the University of Michigan, president of the History of Science Society, who treated the discovery of the barometer as one phase, and an important one, of the scientific renaissance that took place in the sixteenth century. He was followed by Prof. G. S. Brett, of the University of Toronto, who dealt with the remarkable effect of the discovery on contemporary thought, particularly as it affected the relations between science and theology, and the ideas of the structure and properties of matter.

The evening meeting was held in the McLennan Laboratory of the University of Toronto, under the chairmanship of Dr. J. Patterson, controller of the Canadian Meteorological Service, who opened the proceedings by repeating the Toricellian experiment before a large audience. Mr. W. E. K. Middleton, of the Meteorological Office, then gave an illustrated lecture on the subsequent history of the barometer, showing many slides of interesting instruments developed throughout the past three hundred years. Finally, Prof. John Satterly, of the University of Toronto, presented a paper on the applications of the barometer in physics and chemistry, and emphasized the need for considerable precision when the barometer is used in physical research. It is hoped to publish these papers in the Journal of the Royal Astronomical Society of Canada.

\section{The Chinese Medical Journal}

THE reappearance of the Chinese Medical Journal, the publication of which, says the Lancet (559, Oct. 30 , 1943), was suspended by the occupation by the Japanese of the Chinese Medical Association's offices, coincides with the publication of a book by one of the editors of the Journal, Dr. Szeming Sze, entitled "China's Health Problems". Dr. Sze, who was educated at an English public school, at the University of Cambridge and at St. Thomas's Hospital, is also general secretary of the Chinese Medical Association, which now has o.fices at Washington, the address of which is P.O. 6096. Reviewing Dr. Sze's book, the British Medical Journal (580, Nov. 6, 1943) indicates the magnitude of China's health problems. The morbidityrate is 4 per cent of the population, which means that, in any one day, about 16 million people are ill in China. To treat these there are, in the whole country, 12,000 doctors and 38,000 hospital beds. The usual medical standards require that there should be at least 266,000 doctors and 2 million hospital beds. As things are, many Chinese people still rely exclusively on native methods of treatment. Anyone who is interested in one aspect of these should read the article on Chinese Anthelmintic Prescriptions from the Han period (about 217 A.D.) to the present time (1940) by C. S. Chao, in the Chinese Medical Journal (57, 251-289; 1940).

It is proposed to publish the Chinese Medical Journal quarterly from the United States until the end of the War, and at the same time to issue from Chungking a medical digest in the Chinese language. The other editor of the Journal is Dr. J. Heng Liu. The first issue of the newly published Journal includes accounts of typhus fever in Kunming and Shanghai, and articles on malaria, cholera and plague. The work of the Weishengshu Anti-epidemic Corps, which sends mobile units from Chungking all over free China, is described. It is stated that Japanese aeroplanes dropped parcels of grain and rags, containing plague-infected fleas, over Changteh in November 1941 ; a few days later bubonic plague broke out in the city. News is also given of various agencies and relief organizations now at work in China. The Henry Lester Institute at Shanghai is still active, but its director is now Japanese. The Peking Union Medical College and Hospital are, however, closed and their director, Dr. H. S. Houghton, has been interned.

\section{Train Orders by Facsimile Telegraphy}

Facsimrle telegraphy is one of the devices recently called upon by the railways to help meet the unprecedented demands of to-day. It has many advantages over other forms of communication for several rail. way applications. For example, its inherent accuracy makes it an ideal method for the handling of train orders and once the order is prepared for transmission it need never again be copied manually. The possibility of transmission error is greatly reduced by the fact that the method can operate through extremely high levels of interference. Simplicity of operation and the ease with which duplicate copies may be secured are additional advantages. Automatic recorders, housed in small shacks along the right-of-way, are located at sidings, branches, crossings-wherever a train might be required to stop. Recorders may also be installed in small stations where telegraph service is not provided. An automatic transmitter, under control of the operator for the district, is arranged so that he may transmit orders to any of these recorders.

Since the recorders are entirely automatic, the order may be transmitted in advance of the arrival of the train. The circuit is arranged so that the transmitter may be set by the operator to send automatically as many copies of the order as are required by the various members of the train crew, and the orders are thus secured with a minimum of time and effort. The time and effort required of the operator are equally slight; he dials the desired recorder, sets an indicator to the desired number of copies, and drops the order into the machine. The messages simply roll out of the machine into a receptacle whether or not there is anyone present to receive them. A recorder readily adapted to such service was developed by the Western Union Telegraph Company for use in conjunction with automatic transmitters, and the equipment comprises what is probably the most completely automatic telegraph system yet devised. An article by J. H. Hackenberg (Elec. Comm., 21, No. 2 ; 1943) describes and illustrates the new equipment and its mode of operation.

\section{A South American Review of Newton's Work}

IN a paper entitled "El Tricentenario De Newton", Mario Bunge examines five different aspects of Newton's work (Buenos Aires: Universidad Obrera Argentina Instituto Cientifico, Seminario De Filosofia, November 1942. Pp. 8). The first of these is his discovery and application of the infinitesimal calculus, a discovery which unfortunately caused some unpleasant feeling with Leibniz, though, as is pointed out, each represented a distinct school so that their contributions can be regarded as complementary. 
Secondly, Newton was responsible for the introduction of the deductive method in the natural sciences and so rendered signal service to mankind as the founder of mathematical physics, which has been the basis of so much in science for two and a half centuries. Then, his rational mechanics had a profound influence for many generations. Newton's differential equations showed how the state of the universe today is the result of all its past history, and its future history could be determined by its present. This required a strict determinism which obsessed the minds of men of science for a long period, though in comparatively recent times there has been a strong reaction against it. His work on optics showed his ability as an experimental physicist. Newton's subordination of optics to mechanies, far from enhancing progress, was a principal cause of the lack of progress in optics during the eighteenth century. An ironical result of his experiments with diffraction and interference was the death-knell a century later of his corpuscular theory of light. Lastly, Newton's philosophical work must not be forgotten. Space and time were objective and independent of our perception of them, according to Newton, and were not a priori representations which served for the foundations of all external intuitions. Force, energy, mass, motion, as well as space and time, were all objective entities for Newton. His work must be considered a model of the systematic application of scientific mothoda model of the power of reason to investigate the natural, controlling and ruling it, by placing it at the service of progress, material, cultural and moral, of humanity.

\section{Earthquakes Recorded during September}

The U.S. Coast and Geodetic Survey has determined the epicentres of six earthquakes occurring between Sept. 5 and 20 . The first was on Sept. 5 from lat. $0^{\circ}$ long. $125^{\circ} \mathrm{E}$., which is in the Molucca Passage east of the island of Celebes in the East Indies; time at origin, $8 \mathrm{~h} .34 \cdot 8 \mathrm{~m}$. The second was on Sept. 6 from an epicentre lat. $53 \cdot 2^{\circ} \mathrm{S}$. long. $159 \cdot 4^{\circ} \mathrm{E}$., which is north-east of the Macquarie Islands, south-west of New Zealand; time at origin, $3 \mathrm{~h} .41 \cdot 5 \mathrm{~m}$. The third was on Sept. 10 from an epicentre lat. $18 \cdot 9^{\circ} \mathrm{N}$. long. $67^{\circ} \mathrm{W}$., which is near the north-west coast of Porto Rico in the West Indies, time at origin being $2 \mathrm{~h} .31 \cdot 6 \mathrm{~m}$. The fourth was also on Sept. 10, from an epicentre near lat. $35 \cdot 1^{\circ} \mathrm{N}$. long. $133 \cdot 3^{\circ} \mathrm{E}$., which is in the Pacific Ocean west of California, time at origin being $8 \mathrm{~h} .36 \cdot 9 \mathrm{~m}$. The fifth was on Sept. 11, from an epicentre near lat. $16 \frac{1}{2}^{\circ} \mathrm{S}$. long. $173^{\circ} \mathrm{W}$., which is in the Pacific Ocean between Samoa and the Friendly Islands and east of Fiji. Time at origin was $19 \mathrm{~h}$. $34 \mathrm{~m}$. The sixth was on Sept. 20 from an epicentre near lat. $19 \frac{1}{2}^{\circ} \mathrm{N}$. long. $109^{\circ} \mathrm{W}$., which is in the Pacific Ocean west of Mexico and north-east of Revilla Gigedo Island. Time at origin was $00 \mathrm{~h} .53 \cdot 7 \mathrm{~m}$.

Earthquakes were registered at Kew on Sept. 5 at $08 \mathrm{~h} .49 \mathrm{~m}$. $11 \mathrm{~s}$. from an epicentre $12,000 \mathrm{~km}$. distant; on Sept. 6 at 04h. 01m. 32s. from an epicentre $18,700 \mathrm{~km}$. distant (maximum amplitude at Kew $440 \mu)$; and on Sept. I0 at $08 \mathrm{~h} .49 \mathrm{~m}$. $32 \mathrm{~s}$. from an epicentre $9,560 \mathrm{~km}$. distant (maximum amplitude $250 \mu$ at Kew). All times are in Universal Time and interpretations and calculations are provisional.

On October 26 an earthquake was felt in San Francisco. Some telephones were put out of action, some windows broken and some articles jolted off shelves.

\section{Announcements}

The title of professor of technical optics in the University of London has been conferred on Dr. L. C. Martin in respect of the post held by him at the Imperial College of Science and Technology.

THE University of Oxford has accepted an offer from the Lord Nuffield Provincial Hospitals Trust of $£ 8,000$ a year for research in plastic surgery and for training in that branch of surgery.

During 1943 the Royal Society of South Africa elected the following fellows : John G. Rose, formerly Government analyst and chief chemist to the S.A. Railways and Harbours, Cape Town, for his valuable applications of chemistry in the field of engineering; and Hillel A. Shapiro, assistant Government pathologist, Cape Town, for his work on experimental physiology and malnutrition. The Abbé Henri E. P. Breuil, the distinguished archæologist, at present attached to the University of the Witwatersrand, Johannesburg, has been elected an honorary fellow of the Society.

The Charles L. Mayer Award for 1943 will be made by the National Science Fund of the U.S. National Academy of Sciences for an outstanding contribution to present-day knowledge of factors affecting the growth of animal cells, with particular reference to human cancer. In addition, the advisory committee requests recommendations from scientific men of persons whose present work is in this field and who are achieving outstanding results. The closing date for the receipt of manuscripts and published articles is January 15, 1944; they should be sent to the National Science Fund of the National Academy of Sciences, 515 Madison Avenue, New York 22, N.Y.

Messra. H. K. Lewis and Co., Ltd., 136 Gower Street, London, W.C.1, have issued a price list of certain German publications which are being repro. duced in the United States by photo-offset process under authorization of the Alien Property Custodian in Washington. It includes books on mathematics, physics and chemistry, mainly published during the period 1930-40; among the titles are many standard works of references, as well as recent technical books. Messrs. Lewis are accepting orders, but anticipate a delay of three months in obtaining copies.

Six popular lectures on astronomy have been arranged by the Royal Astronomical Society and the British Astronomical Association, and are being given on Fridays at the Royal Astronomical Society's rooms in Burlington House, Piccadilly, London, W.l, for members of the British and Allied Forces. The first was given on December 3 by Sir James Jeans on "Photographic Astronomy". On December 17 Prof. W. M. Smart is speaking on "The Origin of the Earth". Succeeding lectures will be given on January 7, by Mr. B. M. Peek, on "The Planets and Planetary Observations" ; on January 21, by Prof. H. Dingle, on "The Movements of the Stars"; on February 4, by Mr. Will T. Hay, on "Life on other Planets"; and on February 18, by Mr. F. J. Har. greaves, on "The Determination of Stellar Distances". The lectures begin at 6.30 p.m. Admission is free by tickets obtainable from Service Organizations or from the Assistant Secretary, Royal Astronomical Society, Burlington House, Piccadilly, London, W.1 